\title{
ПРОМОТИВНЕ (АКЦИЈСКЕ) ПОНУДЕ У РЕКЛАМНОМ ДИСКУРСУ ИСКАЗАНЕ НЕЗАВИСНОСЛОЖЕНОМ РЕЧЕНИЦОМ СА КОНДИЦИОНАЛНИМ МЕЂУКЛАУЗАЛНИМ СЕМАНТИЧКИМ ОДНОСОМ ${ }^{1}$
}

\begin{abstract}
САЖЕТАК
У раду се испитују независносложене реченице, пре свега оне у саставном односу, у којима је видљива семантика кондиционалности. Примери су ексцерпирани из рекламног дискурса: првом клаузом даје се препорука/понуда одређеног производа/радње, док се другом износе последице, увек позитивне по судбину саговорника (читаоца/купца), које ће наступити уколико се изврши препоручена радња у првој клаузи. За ступање на снагу тих позитивних последица задужен је сам говорник - најчешће одређени бренд/компанија, а оне су конкретизоване у виду разних поклона, награда, попуста, бонуса и сл. Осим лексичке семантике глагола који учествују у грађењу предиката прве и друге клаузе, посебна пажња даје се анализи синтаксичке структуре оваквих реченица: предикат прве клаузе готово је увек у императиву, док је предикат друге у облику футура првог или у другим глаголским облицима којима се исказује будућност (пре свега у презенту, али и у императиву).
\end{abstract}

КљУЧНЕ РЕЧИ: кондиционалност, независносложена реченица, саставне реченице, реклама, промоција, понуда.

\footnotetext{
${ }^{1}$ Рад представља део истраживања у оквиру докторске дисертације под насловом Кондиционалне конструкиије у стандардном српском језику, а настао је као резултат рада на пројекту Савремени српски језик: синтаксичка, семантичка и прагматичка истраживања (178004), који финансира Министарство просвете, науке и технолошког развоја Републике Србије.
} 


\section{1. Увод}

Предмет овог рада представљају независносложене реченице, најчешће али не и нужно двопредикатске, које међусобно стоје у условнопоследичном односу. Оне су формално најчешће у саставном, а понекад и у супротном односу, док је на значењском плану присутна и семантика кондиционалности. Овакав семантички однос условљен је како лексичком семантиком глагола тих двеју предикација тако и глаголским облицима који заступају дате предикације.

Примери ових реченица веома су фреквентни у рекламном дискурсу, посебно у одређеним „промоцијама”, „,акцијама”, „(специјалним) понудама”, „попустима/снижењима”, па су стога рекламе послужиле као изузетно богат корпус за ексцерпцију оваквих реченица, корпус 'засићен' наведеним конструкцијама. Посматране су, пре свега, званичне интернетске и фејсбук/инстаграм странице појединих брендова и трговинских ланаца, затим онлајн-продавнице, као и званичне странице телекомуникационих компанија. ${ }^{2}$ Будући да је оваква реченична форма веома честа у рекламама, а ограниченост дужине овог рада не дозвољава бављење свим таквим конструкцијама, за анализу је одабрана само једна група примера: она у којима се првом клаузом препоручује/нуди неки производ/радња, а другом обећава одређена погодност саговорнику, ${ }^{3}$ и то најчешће конкретна погодност: у виду награда, поклона, попуста и сл., за чије је извршење

${ }^{2}$ Највећи број примера преузет је са званичних страница телекомуникационих компанија: mts.rs, moj.mts.rs, telenor.rs, vipmobile.rs, потом са фејсбук и инстаграм страница разних брендова - козметичких препарата: Биодерма, Еуцерин; прехрамбених производа: Трик, Прима; електронских уређаја: Самсунг, Хуавеј, Тесла; званичне странице трговинских ланаца и издавачких кућа: Гомекс, Универекспорт, Техноманија, Сигнал плус, Том Тејлор, Лагуна. Када је у питању рекламирање брендова, предност се дала ексцерпцији примера са званичних фејсбук страница, које, због популарности ове друштвене мреже, допиру до највећег броја читалаца, те се промоције и акције постављају готово свакодневно.

3 „Саговорник је лице које заједно са говорним лицем конституише говорну ситуацију без обзира на то да ли је комуникација усмена или писмена или се остварује неким другим медијем" (дакле, саговорник подразумева и читаоца, и корисника, и купца, односно било ког анонимног, фиктивног или неодређеног саговорника) (Поповић 2005: 660). 
задужен сам говорник (компанија/бренд). ${ }^{4}$ Иако се са сигурношћу може рећи да се овде ради о врсти препоручивања, 5 за овакве конструкције Павица Мразовић користи термин „понуда”, издвајајући понуду као засебан говорни чин у коме ,govornik pokušava da podstakne sagovornika na određeni postupak ili ponašanje koji bi oboma doneli neku korist.” (Mrazović 2009: 708). Управо на примеру погодбених реченица (а и примери у овом раду лако се могу трансформисати у погодбене реченице) ауторка објашњава да „u odnosu govornik : sagovornik postoji u stvari pogodbeni odnos: „Ako ti meni..., onda ja tebi...", pa u svakoj ponudi ima i elemenata "pogađanja'." (Isto: 709). ${ }^{6}$ С обзиром на то да понуда обухвата и друкчије исказе, који неће бити предмет овог

4 у раду се неће посматрати примери слични овима, а такође фреквентни у рекламном језику, чијом се другом клаузом износе позитивне последице које ће задесити купца након примене одређеног производа, а за чију истинитост говорно лице само гарантује/обећава, не предузимајући и конкретну акцију (као што је то случај код попуста, поклона, бонуса, бодова и сл.), нпр. Izaberite svoju omiljenu Eucerin Anti-age liniju koja odgovara vašoj koži i uživajte/(uživaćete) u blistavom izgledu bez finih linija i bora! (FB, EU, 9. 9. 2019). О оваквим примерима говори и Вера Васић у својој опсежној студији о рекламном огласу, наводећи примере са комбинацијом императива и футура првог: ,, između kopulativne koordinirane klauze s predikatom u

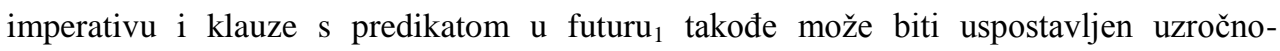
posledični odnos (Pranjković 1984: 69). Drugom klauzom označava se uzrok tipa motiva, kojim se obrazlaže predlog izrečen prvom klauzom. Pošto se na pragmatičkoj razini ovim klauzama izražavaju predlog i obećanje, one se mogu smatrati i supstituentima složene rečenice s kondicionalnom klauzom namesto klauze s imperativnim predikatom.” Ауторка наводи примере старијих и (тада) новијих огласа у српском језику: „ЧИТАЈ, УЗМИ, НЕЋЕШ СЕ КАЈАТИ” (1897) „Ugradite stambene krovne prozore VPO i imat ćete ugodan potkrovni stan!" (1985) (1995: 139-140).

5 „Препорука садржи објекат који се препоручује, као и елеменат изразито позитивног вредновања тог објекта” (Пипер 2005: 669), ,...inicijator ovog govornog čina na osnovu kompetencije upućuje sagovornika na akciju” (Mrazović 2009: 721), „илокутивна функција препоруке може да се одреди као 'анимирање саговорника на чин који је у интересу саговорника”” (Поповић 2005: 1033). Све наведено одлика је и исказа који су предмет овог рада.

${ }^{6}$ И у РМС код одређења понуде истакнута је акција и говорника и саговорника, односно елеменат сарадње: 1. изјава о жељи, готовости да се некоме помогне, да се с неким сарађује итд. 
истраживања, ${ }^{7}$ искази којима се бави овај рад названи су „промотивним (акцијским) понудама". Основ за овакву квалификацију понуде јесте напросто њено именовање у корпусу: наиме, испитиване конструкције на сајтовима телекомуникационих компанија углавном се наводе под картицом насловљеном „Промоције”, док сајтови одређених трговинских компанија и брендова претежно имају ,акције” на продају својих производа, што је и експлицирано употребом наведених лексема. ${ }^{8}$ у оба случаја најчешће постоји временски рок у ком је одређена акција/промоција актуелна, што значи да ће се погодности односити само на оне читаоце који тај задати рок 'испуне'. Слични су и примери наградних игара. Од саговорника се тражи да испуни неку радњу, од које често, посредно или непосредно, има користи и сам говорник (нпр. 'подела' рекламе на профилни зид, врло популарна на друштвеним мрежама, којом се заправо 'проширује' домен рекламирања производа), а саговорнику се заузврат отвара могућност да добије „вредне награде", што је експлицирано у другој клаузи (неретко управо наведеном синтагмом).

\section{2. Анализа корпуса}

Прва и друга клауза независносложене реченице најчешће су повезане везником $u$ и стоје у саставном односу, а могу бити повезане и везником $a$, формирајући саставни или, ређе, супротни однос. Веза може бити и асиндетска, без експлицираног везника. Предикат прве клаузе најчешће има облик императива и осталих средстава са значењем императивности (пре свега презент модалног глагола „моћи”), док је предикат друге клаузе (1) у облику футура првог или (2) у облику презента глагола имперфективног вида, затим (3) у презенту глагола „моћи”, па чак и (4) у императиву. (5) Обе предикације могу бити формализоване и презентом глагола перфективног

\footnotetext{
${ }^{7}$ Нпр. Узми овај колач.

8 Ова значења лексема ,акција” и „промоција” нису наведена у РMC. Најближе значење лексеме „промоција” ономе које се јавља у испитиваном корпусу јесте четврто наведено значење у најновијем издању Великог речника страних речи $u$ израза, аутора Ивана Клајна и Милана Шипке, 4. скуп маркетиншких активности неког произвођача којима упознаје и обезбеђује тржиште за свој нови производ.
} 
вида, а шесту групу (6) чиниће примери у којима је прва клауза са елидираним предикатом, предикација је исказана именским изразима.

У свим наведеним групама првом клаузом износи се директив, а другом се исказује последица која ће наступити (сигурно или можда) уколико се изврши задати директив, а која је обавезно позитивна по судбину саговорника/читаоца (у нашим примерима, готово је увек реч о потенцијалном купцу/кориснику препоручених производа). Првом клаузом заправо се износи услов потребан за испуњење радње исказане другом клаузом, те се ове реченице врло лако могу трансформисати у зависносложену реченицу са условном клаузом (нпр. Kupite bilo koji Nivea Sun proizvod i dobićete jedan od sledećih poklona: lopta za plažu, japanke, frizbi. $\rightarrow$ Ako kupite bilo koji Nivea Sun proizvod, dobićete jedan od sledećih poklona: lopta za plažu, japanke, frizbi).

\section{1. Тип1: $\mathrm{V}_{1 \text { (Imper) }}+\mathrm{V}_{2 \text { (Fut1) }}$}

У првом типу комбинације глаголских облика, прва предикација формализована је императивом, а друга футуром првим. Првим предикатом саговорнику се најчешће препоручује да „купи” одређени производ (а јављају се и глаголи сличне семантике: „потражити”, „изабрати/одабрати” и сл.), а другим предикатом износи се позитивна последица која ће уследити уколико саговорник изврши директив - најчешће је реч о неком поклону, другом производу, погодности у виду попуста, бонуса и сл. Предикат је у највећем броју примера лексикализован глаголом „добити (на поклон)”, „остварити (попуст)”. Неретко, поред куповине, постоји и додатни услов, експлициран у првој клаузи - одређени временски рок, одређена новчана вредност куповине и сл., или се пак куповина односи само на одређену линију производа једног произвођача.

Kupite bilo koji Nivea Sun proizvod i dobićete jedan od sledećih poklona: lopta

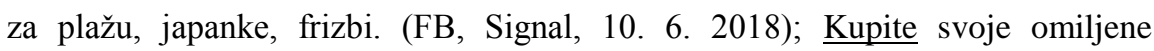
preparate $u$ vrednosti preko 1000 dinara i na poklon ćete dobiti komplementarni preparat koji će upotpuniti negu vaše kože. (FB, EU, 1. 3. 2019); Potražite nova promotivna pakovanja AQUAporin light i AQUAporin UV hidratantnih krema i na poklon ćete dobiti Dermato Clean 3 u 1 Micelarni fluid za čišćenje lica. (FB, EU, 4. 7. 2018); Odaberite vaš omiljeni Eucerin Dezodorans i još jedan ćete dobiti na poklon! (FB, EU, 21. 6. 2018); U toku trajanja promocije, ovde možete 
da zaključite ugovor ili obnovite ugovor za BOX 4 paket na 24 meseca i, pored već postojećih pogodnosti za BOX 4 paket, ostvarićete specijalni popust za kupovinu mobilnog telefona. (mts.rs, 26. 9. 2019); Potražite svoje OMILJENE Eucerin preparate u apotekama od 11. do 13. aprila, obradovaće vas popust od $20 \%$ ! Dani Eucerina počinju! (FB, EU, 10. 4. 2019). ${ }^{9}$

\section{2. Тип2: $\mathrm{V}_{1 \text { (Imper) }}+\mathrm{V}_{2 \text { (Prez impf) }}$}

Уз императив у првој клаузи, може се наћи и презент глагола имперфективног вида у другој клаузи, тзв. презент за планирану будућност, иначе чест у савременом српском језику (Танасић 2005: 384). Милка Ивић истиче да презент долази у обзир онда кад се жели нагласити да у моменту саопштавања постоји решеност да се нека радња у будућности изврши (1981), и њиме се исказује извесност, сигурност, поузданост наступања радње. Коментаришући високу учесталост ове појаве у савременом српском језику у различитим функционалним стиловима, посебно у разговорном, журналистичком и књижевноуметничком, Срето Танасић истиче да, иако се њоме некада постизала већа ефектност саопштавања, па је имао и додатну стилску функцију, ,данас су разговорни стил и журналистички презасићени овим видом транспоновања презента; у новинама је у одређеним позицијама то чак постало клише, у насловима на пример. У таквим случајевима мало остаје од ефектности коју он може да да саопштењу." (Танасић 2005: 384385). Ова комбинација глаголских облика региструје појаву истих глаголских лексема као што је то случај са типом 1: најчешће се јавља глаголски пар „купити : добити”. У другој клаузи појављује се и глагол „чекати/очекивати”, који својом лексичком семантиком указују на будућност радње. Испуњење радње у првој клаузи довољан је услов за ступање на снагу

${ }^{9}$ Сви примери у раду наводе се у 'оригиналу', тј. у облику у ком су пронађени на сајтовима: остављена су велика почетна слова појединих речи, графичко истицање назива производа, оригинална транскриптивна решења, као и многе језичке и правописне грешке (врло фреквентна погрешна примена присвојне заменице „Ваш” уместо „свој”, фреквентна употреба императива „освојите/освоји” уместо „освојте/освој” - заправо, правилан облик није регистрован ни у једном примеру, погрешна позиција енклитика, погрешно писање полусложеница и сложеница итд.). Подвлачењем је обележен први предикат, а болдом други, док су додатни услови у првој клаузи, исказани најчешће прилошким одредбама, обележени косим словима. 
радње у другој клаузи (што неће бити случај у свим примерима типа 3 и типа 4). Ова комбинација знатно је чешћа од типа 1 , што је условљено пре свега врстом корпуса - карактеристикама рекламног дискурса.

У последња два примера клаузе су повезане везником $a$, а супротност је успостављена између говорника и саговорника, заправо се истиче контраст између онога што даје говорник и онога што даје саговорник. У таквим примерима још је израженији однос погодбе између говорника и саговорника, а други предикат је у 1. лицу.

Obavi kupovinu online i na poklon dobijaš držač za auto i bluetooth slušalice. (MTS, 2. 8. 2018); Izaberi MyKi Touch pametni sat za svoje dete i dobijaš set za likovno. (FB, Vip mobile, 2. 9. 2018); Do kraja septembra izaberite: 3 Bosch uređaja i treći najjeftiniji platite sa $50 \%$ popusta ili 5 Bosch uređaja i peti najjeftiniji dobijate za 1 dinar. (FB, Tehnomanija, 16. 9. 2018); Drage dame, poručite Vaš omiljeni proizvod ovaj vikend i od nas dobijate gratis dostavu! ***vikend akcija*** (FB, Bellisima Shop, 3. 3. 2017); Kupite putno osiguranje, a na poklon dobijate osiguranje kuće ili stana. (FB, Generali Srbija, 9. 8. 2019); Kupi putno osiguranje i na poklon dobijaš osiguranje kuće ili stana dok si na putu. (FB, Generali Srbija, 16. 9. 2019); Kupi 1kg ili 2x500g ili 4x250g i dobijaš CEGER GRATIS! (FB, Gomex, 28. 9. 2018); Kupi Samsung telefon S9, S9+ ili Note9 i dobijaš sjajni Samsung Gear S3 sat na poklon. Samo do 5. 11. 2018. (FB, Samsung, 15. 10. 2018); Putem online prodavnice potpiši ugovor ili obnovi postojeći u bilo kojoj NEO ili интарифа sa ili bez uređaja i dobijaš dodatni jedan gigabajt za surf svakog meseca, tokom 24 meseca ugovorne obaveze. Promocija traje do 31. 10. 2019. (vipmobile.rs, 26. 9. 2019); Kupite bilo koji Tesla TV i dobijate produženu garanciju od, čak, 5 godina! (FB, Tesla Info, 27. 9. 2019); Izaberi nove NEO tarife i čekaju te neograničeni minuti i poruke ka svim mrežama, i još više gigabajta za surf, u nacionalnom saobraćaju. (vipmobile.rs, 26. 9. 2019); Odaberi futrolu, memorijsku karticu ili bilo koju drugu dodatnu opremu i očekuje te $10 \%$ popusta prilikom kupovine u online prodavnici. (vipmobile.rs, 26. 9. 2019); Od 19. do 21. septembra možete potražiti svoje OMILJENE Eucerin preparate u apotekama, a mi vam poklanjamo popust od 20\%! (FB, EU, 19. 9. 2019); Specijalna Eucerin ponuda glasi: kupite svoj omiljeni dezodorans ili antiperspirant, a mi vam poklanjamo drugi po $50 \%$ sniženoj ceni! (FB, EU, 17. 6. 2019). 
2.3. Тип3: $\mathrm{V}_{1 \text { (Imper) }}+\mathrm{V}_{2 \text { (Prez moći) }}$

Друга клауза може садржати модални глагол „моћи”, најчешће у презенту, ${ }^{10}$ или структуру „имати могућност”. У том случају последица се може односити на свакога ко изврши задати директив (што је приказано у примерима $a$ ), или се само отвора могућност за остварење последице у другој клаузи (што је случај у примерима б), а значење глагола „моћи” одређује контекст. Управо због способности модалног глагола „моћи” да релативизује извесност наступања последице, ови примери приказани су у посебној групи, иако би се формално могли уврстити у тип 2.

a) Odaberite vaš omiljeni Eucerin Dezodorans i možete dobiti isti preparat na poklon! (FB, EU, 19. 3. 2018); Sipaj 15 litara ili više G-Drive goriva, pokaži „Sa nama na putu“ karticu i možeš osvojiti 50\% popusta na proizvod u Gigatronu. (Inst, sanamanaputu, 1. 10. 2018).

б) Podelite avgustovski akcijski katalog na svom zidu i možete osvojiti jednu od tri nagrada koje delimo svake subote za vreme trajanja kataloga. (FB, Signal, 5. 8. 2018); Kupi dva proizvoda iz Sebium linije i imaš mogućnost da osvojiš karte za Džastinov koncert u novembru u Zagrebu (*od kojih jedan mora biti Sebium Global) (FB, Bioderma, 10. 10. 2016).

\section{4. Тип4: $\mathrm{V}_{1 \text { (Imper) }}+\mathrm{V}_{2 \text { (Imper) }}$}

Други предикат може бити формализован императивом. Такав императив, као што је случај и са модалним глаголом „моћи”, може се односити на последице које ће уследити свакоме ко испуни радњу првог императива (група $a$ ), или се пак та радња односи само на појединце који испуне директив, односно само постоји могућност за њеним остварењем, док је испуњење директива прве клаузе неопходан, али не и довољан услов (група б). Осим глагола „купити” и њему сродних „изабрати/одабрати” (одређени производ/пакет), у првом предикату саговорнику се препоручује да „се региструје/креира налог”, односно да „инсталира/активира” одређену апликацију, што је у језику нових технологија сродно куповини, а другим предикатом износе се разне погодности, па се, као и у типу 1 , јављају

10 Могао би доћи у обзир и потенцијал, као и футур први, (а и употреба речце „можда”), али је у свим случајевима испитиваног корпуса уочен презент. 
глаголи „освојити/остварити (попуст)”, а чест је и глагол „плаћати”, са обавезном одредбом којом се спецификује начин плаћања (нпр. ,јефтиније”, „без провизије” и сл.). ${ }^{11}$ Примери групе б) чести су у наградним играма, у којима свако учешће не подразумева нужно и освајање награде. Други предикат готово је увек формализован глаголом „освојити”, а услов може бити исказан разним глаголима: „учествовати”, „купити”, „поделити (рекламу на зид)", већ у зависности од врсте игре. У свим примерима другом клаузом заправо се износи мотив за извршење радње прве клаузе (нпр. Инсталирај „,М плати” апликацију и плаћај рачуне за МТС услуге и припејд допуну без провизије. $\rightarrow$ Ако желиш да плаћаш рачуне за МТС услуге и припејд допуну без провизије, инсталирај „М плати” апликаџију).

a) Instaliraj „m plati“ aplikaciju i plaćaj račune za mts usluge i pripejd dopunu bez provizije, putem mobilnog telefona. (FB, MTS, 16. 8. 2018); Izaberi jedan od Box paketa i plaćaj jeftinije usluge fiksne linije, interneta i mts TV-a i to na istom računu. (FB, MTS, 26. 6. 2018); Izaberi tablet ALCATEL PIXI $10 \mathrm{WiFi}$ i otplati ga na 24 rate. (FB, MTS, 5. 6. 2018); Izaberi tarifu, sa ili bez uređaja, i opusti se uz besplatnu komunikaciju prvih 9 meseci. (vipmobile.rs, 25. 9. 2019); Do kraja septembra izaberite: 3 Bosch uređaja i treći najjeftiniji platite sa 50\% popusta. (FB, Tehnomanija, 16. 9. 2018); Pokaži ovaj kupon na kasi u našoj radnji i ostvari 10\% popusta na novu kolekciju! (FB, TOM TAILOR, 26. 8. 2018); Kupite (trik proizvod) i osvojite magičnu svesku! (FB, Trik, 22. 8. 2018); Aktivirajte mts TV GO i besplatno gledajte TV na telefonu, tabletu ili na računaru. Promotivni period traje do 30. septembra 2019. godine. (mts.rs, 26. 9. 2019); Kreirajte jedinstveni korisnički nalog Moj mts za pristup mts portalu i ostvarite sledeće pogodnosti: pregled mts usluga koje koristite, uvid u mts račune i listinge saobraćaja. (moj.mts.rs, 26. 9. 2019); Koristite svoju Eucerin aplikaciju i postanite član Eucerin kluba lojalnosti i ostvarite pravo na poklon. (FB, EU, 26. 11. 2018); Registruj se na Huawei Forum, postavi svoju letnju fotku na bit.ly/HuaweiSummerVibes i osvoji Huawei bodove koje možeš da iskoristiš za kupovinu dodatnog prostora, tema ili aplikacija. (FB, HU, 25. 9. 2019).

б) Kupi Laško osvoji bicikl (FB, Univerexport); Podelite sa nama (fotografiju) i osvojite neku od vrednih nagrada. (FB, Huawei Mobile, 22. 8. 2018); Podeli svoj

11 У овој комбинацији глаголских облика изостаје глагол „добити” у императиву, који је, као што се могло уочити, изузетно фреквентан у осталим комбинацијама. 
omiljeni letnji trenutak i osvoji nagradu! (FB, Prima, 29. 8. 2018); Učestvuj i osvoji poklon! (FB, EU, 29. 5. 2019); Učestvuj u nagradnom konkursu i osvoji električni trotinet. (telenor.rs, 26. 9. 2019); Sakupljaj bodove i izaberi GENERALI PUTNO OSIGURANJE (FB, Generali Srbija, 7. 8. 2019); Pridruži se velikom INSTA PRO 20 foto konkursu i od 15. juna do 6. jula podeli na svom Instagram nalogu fotografiju na zadatu temu i osvoji neku od vrednih nagrada. (FB, HU, 14. 6. 2018); Fotkaj omiljeni oblik, podeli fotografiju na svom Inagram nalogu do 6. jula i osvoji vredne nagrade. (FB, HU, 3. 7. 2018); OPET NAGRAĐUJEMO!!! LAJKUJ, PODELI I OSVOJI POKLON SA SLIKE (FB, Farmasi Kozmetika, 7. 8. 2018); Budi drug, podeli radost i OSVOJI SLATKI MEDENI PAKET! (FB, Medela Srbija, 29. 8. 2019); Poleti, podeli i osvoji! (FB, Air Srbija, 21. 6. 2018).

\section{5. Тип5: $\mathrm{V}_{1 \text { (Prez pf) }}+\mathrm{V}_{2 \text { (Prez pf) }}$}

Поред свих до сада наведених комбинација, у којима је први предикат био граматикализован императивом, он се може наћи и у презенту глагола перфективног вида, а тада је и други предикат у истом облику. Перфективност глагола у презенту утиче на динамичност исказа, а ове реченице често су асиндетске. С. Танасић (2005: 285) овакву транспозицију презента у будућност назива презентом за замишљену будућност (према термину А. В. Бондарка). Како аутор наводи, у случају употребе презента глагола свршеног вида ,он се обично не јавља сам него у низовима; успоставља се режим излагања потпуно симетричан ономе код транспоновања презента у прошлост". И у наведеним случајевима јављају се парови, и то најчешће ,купиш : добијеш”. У оваквим примерима саговорнику се ,догађаји ређају пред очима; свршени презент служи да се пажња читаоца или слушаоца помера са једне радње на другу" (Исто: 385). Ове структуре подсећају на редуковане условне реченице, и то оне које се према времену вршења радње одређују као свевремене (Купии 2 добијеш 3. $\rightarrow$ Ако купиш 2, добијеш 3). Реч је о уопштено личним реченицама.

AKCIJA KUPIŠ 2 DOBIJEŠ 3 (bigcenters.rs, 26. 9. 2019); Kupiš Galaxy S8 i S8+ i dobiješ Samsung Tab 7“! (FB. MTS, 11. 8. 2017); U želji da te iznenadimo i obradujemo osmislili smo akciju KUPIŠ 1 DOBIJEŠ 2. (FB, homeplus, 8. 1. 2018); Velika BAYNA rođendansaka akcija - uuiš 3, dobiješ 4. Akcija važi za kupovinu u svim Ivančić i sin apotekama, kao i našem online shop-u. (bayna.rs, 19. 12. 2018). 


\section{6. Тип6: $\mathrm{N}_{1}+\mathrm{V}_{2}$}

Прва реченица може бити са елидираним предикатом. У том случају, експлициране именске речи заправо представљају материјални услов (тј. материјално средство у сфери услова) за постизање жељених резултата, а у наведеном примеру подразумеван је глагол „сакупити”.

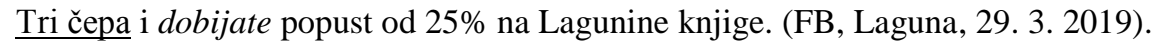

\section{3. Закључна разматрања}

У раду су посматране независносложене реченице са кондиционалним семантичким односом (најчешће саставне, двопредикатске) којима се препоручује/нуди одређени производ или радња, и износе позитивне последице те препоруке (поклони, попусти и сл.), а за корпус је узет рекламни дискурс, пре свега сајтови и фејсбук странице одређених произвођача. Издвојене су могуће комбинације глаголских облика предиката. Уочено је да су чешће оне реченице у којима је прва предикација формализована императивом а друга презентом глагола имперфективног вида, од оних код којих је прва предикација формализована императивом а друга футуром првим. У оба случаја, прва предикација најчешће је лексикализована глаголом „купити” а друга глаголом ,добити (на поклон)” или „освојити/остварити”. Очигледна предност презента глагола имперфективног вида одлика је журналистичког стила, па и текстова реклама. Исте глаголске лексеме појављују се и у примерима у којима су обе предикације граматикализоване презентом глагола перфективног вида. Такве конструкције нарочито подсећају на редуковане кондиционалне реченице, без везника, координираних или субординираних. Оба предиката могу бити формализована и императивом, и у том случају услов који је изнет у првој клаузи може а и не мора бити довољан услов за остварење радње друге клаузе (као што је то случај и са употребом модалног глагола „моћи” у другој клаузи). Стога ће употреба императива бити честа у рекламама за наградне игре (у којима 'не добија свако'), а најучесталији глагол другог предикацијског дела јесте глагол ,освојити”. Због овакве природе императива у анализираним реченицама, он се јавља у највећем броју

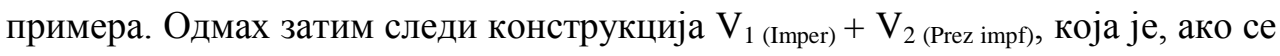
изузму случајеви са императивом у другој клаузи у којима услов прве клаузе 
није и довољан услова за испуњење радње у другој клаузи (тип 3, група б), подједнако честа конструкцији $\mathrm{V}_{1 \text { (Imper) }}+\mathrm{V}_{2 \text { (Imper) }}$ (групи $a$ овог типа).

\section{ЛИТ Р Р А Т У Р А}

Ивић, Милка (1981). Српскохрватски глаголски облици за исказивање појава које постоје у садашњости. Јужнословенски филолог. XXXIII: 12-24.

Клајн, Иван и Милан Шипка (2012). Велики речник страних речи и израза. Нови Сад: Прометеј.

Пипер, Предраг (2005). Семантичке категорије у простој реченици: синтаксичка синтагматика. У: Синтакса савременога српског језика (ур. М. Ивић). Београд: Институт за српски језик САНУ, Београдска књига; Нови Сад: Матица српска. 575-978.

Поповић, Људмила (2005). Комуникативне функције просте реченице. У: Синтакса савременога српског језика (ур. М. Ивић). Београд: Институт за српски језик САНУ, Београдска књига; Нови Сад: Матица српска. 983-1057.

Танасић, Срето (2005). Синтакса глагола. У: Синтакса савременога српског језика (ур. М. Ивић). Београд: Институт за српски језика САНУ, Београдска књига; Нови Сад: Матица српска. 345-470.

PMC: Речник српскога језика, Нови Сад: Матица српска, 2011.

Mrazović, Pavica (2009). Gramatika srpskog jezika za strance. Sremski Karlovci - Novi Sad: Izdavačka knjižarnica Zorana Stojanovića.

Pranjković, Ivo (1984). Koordinacija u hrvatskom književnom jeziku. Zagreb: Sveučilišna naklada Liber.

Vasić, Vera (1995). Novinski reklamni oglas. Studija iz kontekstualne lingvistike. Novi Sad: LDI.

Marina Šafer

PROMOTIONS AND SPECIAL OFFERS IN ADVERTISING DISCOURSE EXPRESSED AS INDEPENDENT COORDINATE CLAUSES WITH CONDITIONAL SEMANTIC RELATIONS

\section{SUMMARY}

This paper showcases coordinate clauses with conditionality semantics. The examples are excerpted from advertising discourse, where the first clause 
recommends/offers to buy a specific product or service, (in most cases using verbs "купити" and "изабрати/одабрати"), while the second clause explains the consequences which always bear a positive outcome for the interlocutor, (reader or buyer), and which will set in if the recommended action of the first clause is fulfilled (in most cases using verbs "добити (на поклон)“, "освојити“, "остварити

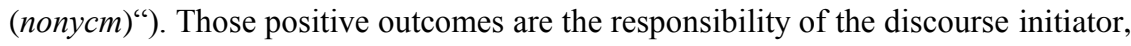
in most cases a specific brand, and they materialize through various gifts, rewards, discounts, etc. Apart from lexical semantics of the verbs which comprise the first and second clause predicates, the paper points to the syntactic structure of these sentences: the first sentence predicate always uses imperative verb forms, while the predicate of the second is Serbian future tense type-I, or other future verb forms: present (especially for imperfective verbs) and imperative mood. Future type-I occurs in the fewest examples.

KEYWORDS: conditionality, coordinate clauses, advertisement, promotion, offer.

Мср Марина Шафер, докторанд Одсек за српски језик и лингвистику Филозофски факултет, Универзитет у Новом Саду 